18. Duve S, Schmoeckel C, Burgdorf WH. Melanocytic hyperplasia in scars: a histopathological investigation of 722 cases. Am J Dermatopathol. 1996;18(3):236-240.

19. Botella-Estrada R, Sanmartín O, Sevila A, Escudero A, Guillén C. Melanotic pigmentation in excision scars of melanocytic and non-melanocytic skin tumors. J Cutan Pathol. 1999;26(3):137-144.

20. Argenziano G, Kittler H, Ferrara G, et al. Slow-growing melanoma: a dermoscopy follow-up study. Br J Dermatol. 2010;162(2):267-273.
21. Beer J, Xu L, Tschandl P, Kittler H. Growth rate of melanoma in vivo and correlation with dermatoscopic and dermatopathologic findings. Dermatol Pract Concept. 2011;1(1):13.

22. Hocker TL, Alikhan A, Comfere NI, Peters MS Favorable long-term outcomes in patients with histologically dysplastic nevi that approach a specimen border. J Am Acad Dermatol. 2013;68(4):545-551. doi:10.1016/ j.jaad.2012.09.031

23. Tallon B, Snow J. Low clinically significant rate of recurrence in benign nevi. Am J Dermatopathol. 2012;34(7):706-709.
24. Goodson AG, Florell SR, Boucher KM, Grossman D. Low rates of clinical recurrence after biopsy of benign to moderately dysplastic melanocytic nevi. J Am Acad Dermatol. 2010;62(4):591-596.

25. Salerni G, Terán T, Puig S, et al. Meta-analysis of digital dermoscopy follow-up of melanocytic skin lesions: a study on behalf of the International Dermoscopy Society [published online November 26, 2012]. J Eur Acad Dermatol Venereol. doi:10.1111/jdv.12032.

NOTABLE NOTES

\title{
A Short History of Tattoo
}

Filippo Pesapane, MD; Gianluca Nazzaro, MD; Raffaele Gianotti, MD; Antonella Coggi, MD

Tattoo is a permanent pigmentation of the skin resulting from the introduction of exogenous substances. If this happens unintentionally-for example, after road injuries-it is called traumatic tattoo. However, the most common tattoos are decorative, related to current fashion or to a symbolic meaning.

The etymological origin of the word tattoo is believed to have 2 major derivations: the first is from the Polynesian word " $t a$ " which means "striking something," and the second is the Tahitian word "tatau" which means "to mark something." This word was introduced in Europe by the English explorer James Cook, who described the Polynesian technique of "tattaw" in his narrative of the voyage.

The oldest example of tattoo dates back to $3000 \mathrm{BC}$ and is represented by a mummy called "Ötzi the Iceman" discovered from the area of the Italian-Austrian border in 1991. ${ }^{1}$ Radiological examination of his bones showed osteochondrosis in areas where tattoos had been present. It has been speculated that these tattoos may have been related to pain relief treatments similar to acupuncture. If so, this practice may have existed at least 2000 years before its previously known earliest use in China. ${ }^{2}$

In ancient times the tattoo spread throughout Egypt and Rome until it was banned by the Emperor Constantine after his conversion to Christianity. Constantine believed that the human image was a representation of God and should not be disfigured or defiled. The practice of tattooing the body was never fully accepted by any of the 3 great mono- theistic religions (Christianity, Judaism, and Islam). Although tattoos were forbidden among Christians by Pope Hadrian I in 787, the habit of tattooing the body survived secretly, especially in some places of Christian worship, like the Sanctuary of Loreto, where the "Friars-Tattooist" ("Frati-marcatori") tattoo, a small devotional sign to the pilgrims, was used.

The reintroduction of the tattoo in the Western world occurred after the ocean expeditions of the 18th century. At the end of the 19th century the use of tattooing spread among highest European social classes: famous "celebrity" tattoos included those of Tsar Nicholas II and Sir Winston Churchill. In recent decades the practice of tattoo has widely spread in the Western world to all social classes, with an increase of complications related to it, such as allergic, lichenoid, granulomatous, and pseudolymphomatous reactions or induction of skin diseases. ${ }^{3}$

Author Affiliations: Fondazione IRCCS Ca' Granda, Ospedale Maggiore Policlinico, University of Milan, Milan, Italy.

Corresponding Author: Filippo Pesapane, MD, Fondazione IRCCS Ca' Granda Ospedale Maggiore Policlinico, Via Pace 9, Milan, Italy (filippopesapane@gmail .com).

1. Spindler K. The Man in the Ice. New York, NY: Harmony Books; 1995:178-184.

2. Dorfer $L$, Moser $M$, Bahr $F$, et al. A medical report from the stone age? Lancet. 1999;354(9183):1023-1025.

3. Goldstein AP. VII. Histologic reactions in tattoos. J Dermatol Surg Oncol. 1979;5(11):896-900. 